BIOFARM

Jurnal Ilmiah Pertanian

ISSN Print: 0216-5430; ISSN Online: 2301-6442

Vol. 15, No. 1, April 2019

\title{
Pengaruh Konsentrasi dan Lama Perendaman Rootone F terhadap Pertumbuhan Stek Mawar (Rosa sp.)
}

\author{
The Influence of Concentration and Long Submersion using Rootone F \\ Toward The Growth of Cutting Rose (Rosa sp)
}

\author{
Salsabila IIma Rohma*1 dan Syakiroh Jazilah", \\ Program Studi Agroteknologi Fakultas Pertanian Universitas Pekalongan \\ *Korespondensi Penulis: salsabilailma@gmail.com
}

\begin{abstract}
ABSTRAK
Mawar (Rosa sp) merupakan salah satu bunga yang paling banyak diminati masyarakat karena penampilannya yang cantik dan indah serta aromanya yang harum dan khas. Penelitian bertujuan untuk mengetahui Pengaruh Konsentrasi dan Lama Perendaman Terhadap Pertumbuhan Stek Mawar (Rosa sp). Telah dilaksanakan di Kelurahan Medono Kota Pekalongan. Rancangan yang digunakan adalah Rancangan Acak Kelompok. Faktor pertama Konsentrasi Rootone F (Tanpa Rootone F, 500 ppm, 1000 ppm dan 1500 ppm), Faktor kedua Lama Perendaman 1 Jam, 2 Jam dan 3 Jam). Variabel pengamatan meliputi kecepatan tumbuh tunas, panjang tunas, jumlah daun, luas daun, jumlah akar, bobot basah akar, bobot kering akar, persentase stek hidup, bobot basah tanaman dan bobot kering tanaman. Hasil penelitian menunjukkan konsentrasi Rootone $\mathrm{F}$ berbeda sangat nyata terhadap kecepatan tumbuh tunas, panjang tunas, jumlah daun, luas daun, jumlah akar, bobot basah akar, bobot bobot kering akar, bobot basah tanaman, bobot kering tanaman. Konsentrasi optimum untuk pertumbuhan stek mawar adalah 1000 ppm. Lama Perendaman menunjukkan berbeda sangat nyata terhadap panjang tunas, jumlah daun, luas daun, jumlah akar, bobot basah akar, bobot kering akar, persentase stek hidup, bobot basah tanaman, bobot kering tanaman, dan tidak berbeda nyata pada kecepatan tumbuh tunas. Hasil terbaik dicapai pada lama perendaman 2 jam. Terdapat interaksi antara perlakuan konsentrasi Rootone $\mathrm{F}$ dan lama perendaman, berbeda sangat nyata terhdap variabel bobot basah akar, bobot kering akar, bobot basah tanaman dan bobot kering tanaman. Kombinasi terbaik dicapai pada konsentrasi Rootone F 1000 ppm dengan lama perendaman 2 jam.
\end{abstract}

Kata Kunci : Stek Mawar, Rootone F, dan Lama Perendaman

\begin{abstract}
Rose (Rosa sp) is one of the most interest flower people like them because they have a good and beautiful appearance and they have a unique fragance. The purpose of research was to know about the influence of concentration and long submersion toward the growth of cutting rose (Rosa sp). This research was done in Medono district pekalongan city. The program that used was Randomized Block Design. The first factor was concentration of Rootone F (without Rootone F, 500 $\mathrm{ppm}, 1000 \mathrm{ppm}$, and $1500 \mathrm{ppm}$ ), the second factor was long submersion (1 hour, 2 hours, and 3 hours). The variable of research was the speed grow of bud, the long of bud, the total of leaves, the wide of leaf,the total of roots, the weight of wet root, the weight of dry root, the presentation of cutting life, the weight of wet plant, the weight of dry plant. The optimum consentration for the growth of rose cuttings is $1000 \mathrm{ppm}$. The long submersion showed the real difference in long of bud,the total of leaves, the wide of leaf, the total of roots, the weight of wet root, the weight of dry root, the presentation of cutting life, the weight of wet plant, the weight of dry plant, has no difference in the real for the speed grow of bud. The best result are achived in 2 hours long submersion. There was interaction between treatment concentration of Rootone $F$ and long submersion, has real difference in vaariable the weight of wet root, the weight of dry root,the weight of wet plant, the weight of dry plant. The best combination was reached in the concentration Rootone F 1000 ppm with the long submersion for two (2) hours.
\end{abstract}

Key Word : the rose cutting, Rootone F, and the long of submersion.

\section{PENDAHULUAN}

Mawar (Rosa sp.) merupakan bunga yang memiliki aroma harum dan khas sehingga banyak diminati masyarakat. Sering digunakan dalam bentuk bunga tangkai untuk acara adat dan upacara penting lainnya, mawar termasuk bunga tabur, bunga potong dan mawar tanam (Purbiati et al. 2002). Tanaman ini menyebar dari wilayah Eropa Timur, Timur tengah dan dataran Cina. Perkembangannya menyebar dari daerah iklim dingin (subtropis) sampai daerah 
panas (tropis), dengan perantara orangorang Belanda mawar mulai masuk ke Indonesia dari Eropa (Tim Karya Tani Mandiri 2010).

Mawar digunakan sebagai bahan baku obat, diantaranya menyembuhkan sekresi empedu, pengobatan aroma terapi, anti kejang dan menurunkan panas badan (daun dan kelopak bunga mawar). Kandungan minyak atsiri yang mengandung senyawa geraniol, phenyl ethyl alcohol, citronellol dan nerol yang menimbulkan aromanya wangi. Geroniol, nerol, tannin, citronellol, terpene, flavonoid, pektin polyphenol, vanillin, karotenoid, stearopten, farsenol, asam geranik, eugenol, feniletilakohol, vitamin B, C, E, dan $\mathrm{K}$ termasuk bahan kimia yang terkandung didalamnya (Windi, 2014).

Berdasarkan data Kementerian Pertanian RI (2012) di Indonesia produksi bunga mawar tahun 2010-2012 menurun. Produksi mawar pada tahun 2010 menurun mencapai 82.351.332 tangkai dan tahun 2011 menurun menjadi 74.319.773 tangkai. Produksinya menurun lagi hingga mencapai 68.624.998 tangkai pada tahun 2012. Produksi menurun disebabkan oleh menurunnya luas panen, dimana pada tahun 2010 mencapai 3.844.434 $\mathrm{m}^{2}$ sampai pada tahun 2012 hanya $750.189 \mathrm{~m}^{2}$.

Penggunaan Rootone $F$ bertujuan merangsang pembentukan akar dan perakaran yang dihasilkan lebih efektif dibandingkan tanpa Rootone F. Stek merupakan cara perbanyakan yang sederhana, pelaksanaannya mudah, dan cepat. Keuntungan cara stek menghasilkan tanaman yang sempurna. Perbanyakan cara stek mempunyai arti penting, sebab dengan bahan sedikit dapat dihasilkan jumlah besar bibit tanaman yang seragam, umur, ketahanan terhadap penyakit maupun sifat tanamannya. Lebih lanjut dikatakan bahwa indikasi keberhasilan penyetekan adalah timbulnya akar dan tunas. Pemberian ZPT salahsatu cara untuk mempercepat timbulnya tunas dan akars (Rochiman dan Harjadi 1973).

Penelitian dilakukan dengan tujuan

untuk: 1.) Mengetahui konsentrasi Rootone-F yang optimum terhadap peningkatan pertumbuhan stek mawar. 2.) Mengetahui lama perendaman yang paling tepat untuk meningkatkan pertumbuhan stek mawar. 3.) Mengetahui pengaruh interaksi antara konsentrasi dan lama perendaman Rootone-F terhadap peningkatan pertumbuhan stek mawar.

\section{METODE PENELITIAN}

Percobaan ini telah dilaksanakan di Kelurahan Medono Kota Pekalongan pada ketinggian \pm 3 meter di atas permukaan laut (dpl), percobaan dilakukan pada bulan September sampai dengan November 2017. Rancangan percobaan yang digunakan adalah Rancangan Acak kelompok (RAK) dengan perlakuan faktorial $4 \times 3$. Faktor pertama konsentrasi Rootone $\mathrm{F}$ yang terdiri atas 4 taraf, yaitu $\mathrm{KO}=$ kontrol (tanpa konsentrasi), $\mathrm{K} 1=500$ ppm, K2 = 1000 ppm, K3 = 1500 ppm. Faktor kedua lama perendaman 3 taraf, yaitu : T1= 1 Jam, T2 = 2 Jam, T3 = 3 Jam. Dengan demikian terdapat 12 kombinasi perlakuan, masing-masing perlakuan diulang tiga kali sehingga seluruhnya ada $(4 \times 3) \times 3=36$ satuan percobaan.

Data yang dihasilkan dianalisis dengan uji $\mathrm{F}$ dan apabila terdapat perbedaan di antara faktor yang di coba, maka analisis dilanjutkan dengan uji BNT dan uji regresi. Khusus lama perendaman dengan uji kontras ortogonal. Variabel yang diamati meliputi : (1) kecepatan tumbuh tunas, (2) panjang tunas, (3) jumlah daun, (4) luas daun, (5) jumlah akar, (6) bobot basah akar, (7) bobot kering akar, (8) persentase stek hidup, (9) bobot basah tanaman, (10) bobot kering tanaman.

\section{HASIL DAN PEMBAHASAAN \\ Pengaruh Konsentrasi Rootone F}

Hasil penelitian menunjukan bahwa perlakuan konsentrasi 1000 ppm berbeda sangat nyata terhadap semua variabel yang diamati dengan pola pengaruh kuadratik. Perlakuan konsentrasi 1000 ppm memberikan pengaruh lebih baik dibandingkan perlakuan konsentrasi 0 ppm, 500 ppm dan 1500 ppm. Di dalam tanaman auksin memacu reaksi-reaksi biokimia dan mengubah komposisinya. Perubahan komposisi kimia di dalam tanaman tersebut mengakibatkan terjadinya pembentukan bagian tanaman seperti akar, tunas, dan daun. Rootone $F$ mengandung NAA dan IBA merupakan auksin yang dapat memacu atau mendorong terjadinya proses-proses fisiologi di dalam tanaman yang meliputi pembelahan, pemanjangan dan pembesaran sel yang juga merupakan proses sebelum terjadinya pembentukan organ-organ tanaman (Wattimena 1988).

Konsentrasi Rootone $F$ berbeda sangat nyata terhadap kecepatan tumbuh tunas, panjang tunas, jumlah daun, luas daun dan jumlah akar. Menurut Lakitan 
(1996) salah satu fungsi akar adalah untuk penyerapan unsur hara. Meningkatnya jumlah akar dapat meningkatkan serapan unsur hara secara maksimal, hal ini akan berpengaruh terhadap metabolisme yang akan meningkatkan pula produksi

Tabel. 1 Matrik Hasil Analisis Data Penelitian Pengaruh Konsentrasi dan Lama Perendaman Terhadap Pertumbuhan Stek Mawar (Rosa sp)

\begin{tabular}{lccccc}
\hline Perlakuan & $\begin{array}{c}\text { Kecepatan } \\
\text { Tumbuh Tunas } \\
\text { (hari) }\end{array}$ & $\begin{array}{c}\text { Panjang Tunas } \\
(\mathrm{mm})\end{array}$ & $\begin{array}{c}\text { Jumlah Daun } \\
\text { (helai) }\end{array}$ & $\begin{array}{c}\text { Luas Daun } \\
\left(\mathrm{cm}^{2}\right)\end{array}$ & $\begin{array}{c}\text { Jumlah } \\
\text { Akar } \\
\text { (buah) }\end{array}$ \\
\hline Konsentrasi & & & & & \\
K0 & $17,77 \mathrm{~b}$ & $6,56 \mathrm{a}$ & $12,82 \mathrm{~b}$ & $57,75 \mathrm{~b}$ & $12,56 \mathrm{~b}$ \\
K1 & $16,73 \mathrm{a}$ & $8,09 \mathrm{~b}$ & $14,12 \mathrm{c}$ & $70,60 \mathrm{c}$ & $13,27 \mathrm{c}$ \\
K2 & $15,61 \mathrm{a}$ & $9,93 \mathrm{c}$ & $16,61 \mathrm{~d}$ & $95,72 \mathrm{~d}$ & $14,76 \mathrm{~d}$ \\
K3 & $20,59 \mathrm{c}$ & $5,73 \mathrm{a}$ & $11,14 \mathrm{a}$ & $50,14 \mathrm{a}$ & $11,80 \mathrm{a}$ \\
\hline Lama Perendaman & & & & & \\
T1 & 17,51 & $7,48 \mathrm{a}$ & $13,37 \mathrm{~b}$ & $68,07 \mathrm{~b}$ & $13,32 \mathrm{~b}$ \\
T2 & 17,06 & $8,15 \mathrm{~b}$ & $14,99 \mathrm{c}$ & $72,74 \mathrm{c}$ & $13,48 \mathrm{~b}$ \\
T3 & 18,45 & $7,10 \mathrm{a}$ & $12,65 \mathrm{a}$ & $64,85 \mathrm{a}$ & $12,48 \mathrm{a}$ \\
\hline Keterangan : Angka yang diikuti huruf yang sama pada kolom dan baris menunjukkan tidak berbeda nyata menurut uji BNT \\
taraf 5\%
\end{tabular}

karbohidrat, protein, lemak yang selanjutnya ditranslokasikan ke seluruh bagian tanaman sebagai pemacu pertumbuhan vegetatif tanaman seperti pada batang, tunas dan daun, maka tunas akan tumbuh lebih cepat dan bertambah panjang. Meningkatnya jumlah akar berpengaruh terhadap bobot basah akar dan bobot kering akar. Bobot basah tanaman merupakan aspek pertumbuhan yang menggambarkan hasil kombinasi faktor-faktor pertumbuhan, seperti panjang tunas dan jumlah akar. Bobot kering tanaman menggambarkan gabungan senyawa organik yang berhasil disintesis dari bahan anorganik terutama air dan karbondioksida (Gardner, 1991).

\section{Pengaruh Lama Perendaman}

Hasil penelitian menunjukkan bahwa perlakuan lama perendaman berbeda sangat nyata terhadap variabel panjang tunas, jumlah daun, luas daun, jumlah akar, bobot basah akar, bobot kering akar, persentase stek hidup, bobot basah tanaman, bobot kering tanaman dan tidak berbeda nyata pada variabel kecepatan tumbuh tunas. Perlakuan lama perendaman 2 jam memberikan pengaruh lebih baik dibanding pelakuan lama perendaman 1 jam dan lama perendaman 3 jam.

Tabel. 2 Angka Rata-rata dan Analisis Statistik Data Komponen Pertumbuhan Stek Mawar

\begin{tabular}{|c|c|c|c|c|c|}
\hline Perlakuan & $\begin{array}{l}\text { Bobot Basah } \\
\text { Akar (gram) }\end{array}$ & $\begin{array}{l}\text { Bobot Kering } \\
\text { Akar (gram) }\end{array}$ & $\begin{array}{c}\text { Bobot Basah } \\
\text { Tanaman (gram) }\end{array}$ & $\begin{array}{l}\text { Bobot Kering } \\
\text { Tanaman } \\
\text { (gram) }\end{array}$ & $\begin{array}{c}\text { Persentase } \\
\text { Stek Hidup } \\
(\%)\end{array}$ \\
\hline \multicolumn{6}{|l|}{ Konsentrasi } \\
\hline KO & $1,26 b$ & $0,73 b$ & $12,26 a$ & $5,39 a$ & $57,78 a$ \\
\hline K1 & $1,47 c$ & $0,85 c$ & $14,43 b$ & $6,34 b$ & $71,11 b$ \\
\hline $\mathrm{K} 2$ & $1,74 d$ & $1,01 d$ & $17,33 \mathrm{c}$ & $7,62 c$ & $86,67 c$ \\
\hline K3 & $1,17 a$ & $0,68 a$ & $11,31 a$ & $4,97 a$ & $53,33 a$ \\
\hline \multicolumn{6}{|c|}{ Lama Perendaman } \\
\hline $\mathrm{T} 1$ & $1,40 b$ & $0,81 b$ & $13,71 b$ & $6,02 b$ & $68,33 b$ \\
\hline $\mathrm{T} 2$ & $1,57 \mathrm{c}$ & $0,91 \mathrm{c}$ & $15,57 \mathrm{c}$ & $6,85 c$ & $75,00 \mathrm{c}$ \\
\hline T3 & $1,26 a$ & $0,73 a$ & $12,21 a$ & $5,37 a$ & $65,00 a$ \\
\hline
\end{tabular}


Lama perendaman zat pengatur tumbuh Rootone $\mathrm{F}$ berbeda sangat nyata terhadap panjang tunas, jumlah daun, luas daun, dan jumlah akar. Hal ini mengakibatkan akumulasi Rootone F lebih bnyak, sehingga auksin dalam kondisi aktif dan efektif mendorong pembelahan dan pemanjangan sel, terutama merangsang pertumbuhan akar. Meningkatnya pertumbuhan jumlah daun dan luas daun dapat meningkatkan serapan air dan unsur hara, maka lebih efektif untuk fotosintesis (Harjadi, 1993).

Lama perendaman Rootone $\mathrm{F}$ berbeda sangat nyata terhadap bobot basah dan bobot kering akar. Meningkatnya pertumbuhan akar mengaktifkan auksin dalam pembelahan sel membentuk jaringan-jaringan baru yang dapat menutup luka akibat pemotongan batang yang disebut kalus. Pembentukan kalus merupakan suatu gejala dari daya tumbuh baru atau daya regenerasi tanaman (Rismunandar, 1992).

Meningkatnya pertumbuhan vegetatif tanaman seperti batang, daun dan akar akan mempengaruhi peningkatan laju proses fotosintesis tanaman sehingga hasil fotosintesis yang dihasilkan bertambah, selanjutnya asimilatnya ditranslokasikan dan diakumulasikan bagian tanaman seperti batang, akar dan daun, hal ini berpengaruh terhadap bertambahnya bobot basah dan bobot kering tanaman (Jumin 2002).

\section{Pengaruh Interaksi antara Konsentrasi Rootone F dan Lama Perendaman}

Hasil penelitian menunjukkan bahwa Konsentrasi Rootone $F$ dan lama perendaman berbeda sangat nyata pada variabel bobot basah akar, bobot kering akar, bobot basah tanaman dan bobot kering tanaman. Kombinasi terbaik dicapai pada konsentrasi Rootone F 1000 ppm dengan lama perendaman 2 jam. Interaksi ini terjadi karena adanya saling berpengaruh antara fungsi Rootone $F$ dan banyaknya Rootone $F$ yang terakumulasi pada batang stek. Rootone $F$ merupakan auksin yang dapat mendorong pembentukan protein dan karbohidrat, sedangkan lama perendaman dapat menentukan banyaknya Rootone $F$ yang terakumulasi pada batang stek. Tohari (1993) menyatakan bahwa dengan adanya pengaruh auksin terhadap perkembangan sel terdapat indikasi yaitu auksin

Tabel. 3 Angka Rata-rata Interaksi Antara Konsentrasi dan Lama Perendaman Rootone F Bobot Basah Akar, Bobot Kering Akar, Bobot Basah Tanaman, Bobot Kering Tanaman.

\begin{tabular}{ccccc}
\hline Perlakuan & $\begin{array}{c}\text { Bobot Basah } \\
\text { Akar (gram) }\end{array}$ & $\begin{array}{c}\text { Bobot } \\
\text { Kering Akar } \\
\text { (gram) }\end{array}$ & $\begin{array}{c}\text { Bobot Basah } \\
\text { Tanaman } \\
\text { (gram) }\end{array}$ & $\begin{array}{c}\text { Bobot Kering } \\
\text { Tanaman } \\
\text { (gram) }\end{array}$ \\
\hline K0T1 & $1,24 \mathrm{~cd}$ & $0,72 \mathrm{bc}$ & $12,02 \mathrm{bc}$ & $5,27 \mathrm{bc}$ \\
K0T2 & $1,33 \mathrm{f}$ & $0,77 \mathrm{e}$ & $12,93 \mathrm{~d}$ & $5,68 \mathrm{~d}$ \\
K0T3 & $1,22 \mathrm{c}$ & $0,71 \mathrm{~b}$ & $11,83 \mathrm{~b}$ & $5,20 \mathrm{~b}$ \\
K1T1 & $1,42 \mathrm{~g}$ & $0,83 \mathrm{f}$ & $13,95 \mathrm{e}$ & $6,13 \mathrm{e}$ \\
K1T2 & $1,70 \mathrm{~h}$ & $0,98 \mathrm{~g}$ & $16,91 \mathrm{f}$ & $7,43 \mathrm{f}$ \\
K1T3 & $1,28 \mathrm{e}$ & $0,75 \mathrm{de}$ & $12,42 \mathrm{c}$ & $5,47 \mathrm{c}$ \\
K2T1 & $1,79 \mathrm{i}$ & $1,04 \mathrm{~h}$ & $17,88 \mathrm{~g}$ & $7,86 \mathrm{~g}$ \\
K2T2 & $2,00 \mathrm{j}$ & $1,16 \mathrm{i}$ & $20,08 \mathrm{~h}$ & $8,82 \mathrm{~h}$ \\
K2T3 & $1,43 \mathrm{~g}$ & $0,83 \mathrm{f}$ & $14,03 \mathrm{e}$ & $6,17 \mathrm{e}$ \\
K3T1 & $1,15 \mathrm{~b}$ & $0,66 \mathrm{a}$ & $10,9 \mathrm{a}$ & $4,83 \mathrm{a}$ \\
K3T2 & $1,27 \mathrm{de}$ & $0,74 \mathrm{~cd}$ & $12,37 \mathrm{c}$ & $5,44 \mathrm{c}$ \\
K3T3 & $1,11 \mathrm{a}$ & $0,64 \mathrm{a}$ & $10,57 \mathrm{a}$ & $4,65 \mathrm{a}$ \\
\hline
\end{tabular}

Keterangan: Angka yang diikuti huruf yang sama pada kolom dan baris menunjukkan tidak berbeda nyata menurut uji BNT taraf $5 \%$

menaikkan tekanan osmotik, menyebabkan pengurangan tekanan pada dinding sel, meningkatkan permeabilitas sel terhadap air, meningkatkan sintesis protein, meningkatkan plastisitas dan perkembangan dinding sel yang meliputi pembelahan sel (cell division) serta pembesaran sel (cell enlargemen).

Kombinasi konsentrasi dan lama perendaman Rootone $\mathrm{F}$ yang sesuai akan membantu meningkatkan bobot basah akar dan bobot kering akar. Kusumo (1984) 
menyatakan bahwa dengan lama perendaman dapat menentukan banyaknya ZPT yang terakumulasi pada jaringan tersebut, oleh karena itu dengan lama perendaman yang tepat, maka unsur-unsur yang terkandung pada ZPT dapat terakumulasi pada jaringan secara optimal, sehingga unsur-unsur yang dibutuhkan untuk pertumbuhan akar terpenuhi.

Bobot kering berhubungan erat dengan bobot basah suatu tanaman, apabila bobot basahnya tinggi maka bobot keringnya juga tinggi. $\mathrm{Hal}$ ini sejalan dengan pernyataan Harjadi (1993), tersedianya unsur hara yang diserap tanaman dapat mendorong pembentukan lemak, karbohidrat dan protein melalui proses fotosintesis, selanjutnya sintesis protein menghasilkan pertambahan dari ukuran sel tanaman serta penimbunan karbohidrat dalam bentuk bobot kering tanaman, bobot kering tanaman merupakan hasil penimbunan hasil bersih asimilat sepanjang pertumbuhan tanaman.

\section{KESIMPULAN}

Berdasarkan hasil penelitian dan pembahasaan dapat disimpulkan sebagai berikut :

1. Konsentrasi Rootone $F$ berbeda sangat nyata terhadap semua variabel yang diamati. Konsentrasi Rootone F optimum untuk pertumbuhan stek mawar adalah 1000 ppm.

2. Lama perendaman Rootone $F$ berbeda sangat nyata terhadap semua variabel yang diamati, kecuali kecepatan tumbuh tunas. Lama perendaman terbaik untuk pertumbuhan stek mawar adalah 2 jam.

3. Terdapat interaksi antara konsentrasi dan lama perendaman Rootone $F$ berbeda sangat nyata pada variabel bobot basah akar, bobot kering akar, bobot basah tanaman, bobot kering tanaman. Tidak berbeda nyata pada variabel jumlah daun, kecepatan tumbuh tunas, panjang tunas, luas daun, jumlah akar, dan persentase stek hidup. Kombinasi terbaik pada pertumbuhan stek mawar dicapai pada konsentrasi Rootone $\mathrm{F}$ dengan konsentrasi 1000 ppm dan lama perendaman 2 jam.

\section{DAFTAR PUSTAKA}

Gardner, F. P, R. B. Pearce dan R. L. Mitchell 1991. Fisiologi Tanaman Budidaya. Universitas Indonesia, Jakarta.

Harjadi. 1993. Pengantar Agronomi. Gramedia. Jakarta. Jumin. 2002. Agronomi. Raja Grafindo Persada. Jakarta.

Lakitan B. 1996. Fisiologi Pertumbuhan dan Perkembangan Tanaman. PT. Raja Grafindo Persada. Jakarta.

Purbiati, T., A. Supandi, E. Retnoningtyas, dan Sarwono. 2002. Pengkajian Sistem Usahatahi (SUT) Bunga Potong Mawar Spesifik Lokasi Lahan Kering. Laporan Hasil Penelitian atau Pengkajian BPTP Karang Ploso, Malang. $10 \mathrm{HIm}$.

Rochiman dan Harjadi, 1973. Diktat Pembiakan Vegetatif. Departemen Agronomi Fakultas Pertanian Institut pertanian Bogor, Bogor.

Tim Karya Tani Mandiri. 2010. Pedoman Bertanam Bunga Mawar. CV. Nuansa Aulia, Bandung. 